\title{
Association of IGF-I gene polymorphisms with milk yield and body size in Chinese dairy goats
}

\author{
Chanjuan Deng ${ }^{1}$, Rongnuan $\mathrm{Ma}^{1}$, Xiangpeng Yue ${ }^{1}$, Xianyong $\operatorname{Lan}^{1}$, Hong Chen ${ }^{1,2}$ and Chuzhao Lei ${ }^{1}$ \\ ${ }^{1}$ Shaanxi Key Laboratory of Molecular Biology for Agriculture, College of Animal Science and Technology, \\ Northwest A\&F University, Yangling, Shaanxi, China. \\ ${ }^{2}$ Institute of Cellular and Molecular Biology, Xuzhou Normal University, Xuzhou, Jiangsu, China.
}

\begin{abstract}
The association of IGF-I gene polymorphisms with certain traits in 708 individuals of two Chinese dairy-goat breeds (Guanzhong and Xinong Saanen) was investigated. Polymerase chain reaction-single strand conformation polymorphism (PCR-SSCP) and DNA sequencing methods were employed in screening for genetic variation. Two novel mutations were detected in the 5'-flanking region and in intron 4 of /GF-I gene, viz., g.1617 G > A and g.5752 G > C (accession D26119.2), respectively. The associations of the g.1617 G > A mutation with milk yield and the body size were not significant $(p>0.05)$. However, in the case of g.5752 G > C, Xinong Saanen dairy goats with the CG genotype presented longer bodies $(p<0.05)$. Chest circumference $(p<0.05)$ was larger in Guanzhong goats with the $G G$ genotype. In Xinong Saanen dairy goats with the $C C$ genotype, milk yields were significantly higher during the first and second lactations $(p<0.05)$. Hence, the $9.5752 \mathrm{G}>\mathrm{C}$ mutation could facilitate association analysis and serve as a genetic marker for Chinese dairy-goat breeding and genetics.
\end{abstract}

Key words: IGF-I gene, dairy goat, milk yield, PCR- SSCP.

Received: August 19, 2009; Accepted: December 9, 2009.

Animal growth is controlled by a complex system, in which the somatotropic axis plays a key role. Genes that operate in this axis are responsible for postnatal growth, mainly by way of growth hormones acting on bones and muscles mediated by insulin-like growth factor I $(I G F-I)$ (Sellier, 2000). Thus, $I G F-I$ is an important growth factor involved in a variety of physiological processes including cell differentiation, embryogenesis, and regulation of metabolism, reproduction, fetal development, and growth (Adam et al., 2000; Shen et al., 2003). The IGF-I gene was mapped on chromosome 5 in bovine (Miller et al., 1991). The $I G F-I$ gene is expressed in most tissues, but mainly in liver (Wang et al., 2003). It encodes a polypeptide of molecular weight of $7.5 \mathrm{kDa}$ with 70 amino acids (Daughaday and Rotwein, 1989). The amino acid sequence of $I G F-I$ is identical in human, cattle, dog, and pig (Nixon et al., 1999).

In the nineties, several lines of evidence revealed an association of the high level of $I G F-I$ in the blood with fast growth in cattle (Barash et al., 1998; Sirotkin et al., 2000). In the following decades, cattle $I G F-I$ gene mutations $(\mathrm{C} / \mathrm{T}$ mutation in the 5 '-flanking region) were found to be associated with the percentage of fat and protein in milk (Ge et al.,

Send correspondence to Chuzhao Lei. Shaanxi Key Laboratory of Molecular Biology for Agriculture, College of Animal Science and Technology, Northwest A \& F University, Yangling, 712100 Shaanxi, China. E-mail: leichuzhao1118@126.com.
2001; Eulalia et al., 2006). However, these results were quite different from Hines' discovery whence no association was found between $\mathrm{C} / \mathrm{T}$ mutation in 5 '-flanking region and dairy production traits in Holstein cattle (Hines et al., 1998). The association of $I G F-I$ gene polymorphism (short random repeat in the 5 '-flanking region) with body weight, both at birth and weaning, has also been described (Li et al., 2004; Moody et al., 1996), although such an association was not found by Curi et al. (2005). Recently, an IGF-I intron 2 polymorphism was found to correlate positively with the twinning rate (Kim et al., 2009).

Dairy goats are numerous in northwest China, among which, the Xinong Saanen (SN) and Guanzhong (GZ) breeds are the best-known, due not only to their tolerance of crushed feed and the local harsh weather, but also to their high milk yield. As it is difficult to culture high quality domestic breeds over a short period by the traditional breeding and genetics methods, the major breeders recently focused on using DNA markers for developing breeds through marker-assisted selection (MAS). Thus, it is important to identify significant associations between polymorphisms within crucial candidate genes and production traits. The aim was to find $I G F-I$ gene SNPs in two Chinese dairy goat breeds and search for the possible associations of these with milk yield and body size. 
708 blood samples were collected from Shaanxi province (440 for GZ breed from Sanyuan Guanzhong dairy goat breeding base in Shaanxi province; 202 for SN breed from Qianyang Saanen dairy goat breeding base in Shaanxi province; 66 for SN breed, also from animal farm in Northwest A\&F University in Shaanxi province). All goats were 2 to 3 years old adults. Measurements were taken for all the individuals $(\mathrm{BH}=$ body height; $\mathrm{BL}=$ body length; $\mathrm{ChC}=$ chest circumference). Based on a 305-day lactation period, the first and second lactation data from each of 202 SN dairy goats from the Qianyang Saanen dairy goat breeding base, were recorded for every goat.

Blood samples were drawn from the jugular vein into curettes containing ACD (anticoagulant citrate dextrose). The samples were stored at $-80{ }^{\circ} \mathrm{C}$ for several weeks, whereupon genomic DNA was extracted with the use of phenol/chloroform (Sambrock et al., 2001).

Based on the goat $I G F-I$ gene sequence published in the GenBank (D26119.2), five pairs of primers were designed. Primer sequences, annealing temperatures and amplicons are listed in Table 1. The P5 primers for the 5' -flanking end in Table 1 referred to those used in cattle (Ge et al., 2001), whereas the remainder were designed in this study.

The final volume of $25 \mu \mathrm{L}$ contained $50 \mathrm{ng}$ of genomic DNA, $0.5 \mu \mathrm{L}$ of each primer $(10 \mathrm{pM}), 2.5 \mu \mathrm{L}$ of a 10xbuffer (including $20 \mathrm{mM} \mathrm{Mg}{ }^{2+}$ ), $0.5 \mu \mathrm{L}$ of dNTPs $(10 \mathrm{mM})$ and $0.25 \mu \mathrm{L}$ of $T a q$ DNA polymerase $(5 \mathrm{U} / \mu \mathrm{L}$ Dongsheng. Guangzhou, China). Amplification was carried out using PCR, under the following conditions: 5 min at $96^{\circ} \mathrm{C}$ for initial DNA denaturation, 35 cycles of denaturation at $94^{\circ} \mathrm{C}$ for $40 \mathrm{~s}$; annealing at $\mathrm{X}^{\circ} \mathrm{C}$ (shown in Table 1) for $40 \mathrm{~s}$ for each pair of primer; extension at $72{ }^{\circ} \mathrm{C}$ for $40 \mathrm{~s}$. The final cycle was followed by a $10 \mathrm{~min}$ extension at $72{ }^{\circ} \mathrm{C}$.

Aliquots of $4 \mu \mathrm{L}$ of PCR products were mixed with $8 \mu \mathrm{L}$ of denaturing solution (95\% formamide, $25 \mathrm{mM}$ EDTA, $0.025 \%$ xylene-cyanole and $0.025 \%$ bromophenol blue) and heated for $10 \mathrm{~min}$ at $98{ }^{\circ} \mathrm{C}$ and chilled on ice. De- natured DNA was subjected to $10 \%$ PAGE $(80 \mathrm{~mm} \times$ $73 \mathrm{~mm} \times 0.75 \mathrm{~mm}$ ) in 1x TBE buffer and constant voltage $250 \mathrm{~V}$ for $15 \mathrm{~min}$, then $160 \mathrm{~V}$ for $2 \mathrm{~h}$. The gel was stained with $0.1 \%$ silver nitrate (Lan et al., 2007). After the polymorphisms were detected, the PCR products of different electrophoresis patterns were sequenced by the Huada Genetic Sequence Company (Beijing, China). The sequences were analyzed with DNASTAR software (Version 7.10, DNASTAR, Madison, USA).

Based on the individual number of different genotypes in analyzed breeds, Hardy-Weinberg equilibriums, genotypic frequencies and allelic frequencies were directly calculated. The statistical software SPSS (Version 16.0) was used to analyze the relationships between the genotypes and traits in goats. The adjusted Linear Model I with fixed effects was used to evaluate the relationships between genotypes and milk yield of Xinong Saanen dairy goats. The model applied was: $Y_{i j k}=\mu+A_{i}+G_{j}+(A G)_{i j}+e_{i j k}$, where $Y_{i j k}$ was the trait measured in each $i j k$ th animal, $\mu$ the overall population mean, $A_{i}$ the fixed effect due to the $i$ th age, $G_{j}$ the fixed effect associated with the $j$ th genotype, $(A G)_{i j}$ the interaction between the $i$ th age and the $j$ th genotype, and $e_{i j k}$ the random error. Effects associated with farm, sex and season of birth (spring versus fall), and the ages of dams and sires, were not considered in the linear model, since preliminary statistical analysis indicated that these effects did not have significant influence on the variability of traits in SN female dairy goats. The adjusted Linear Model II with fixed effects was used to analyze the relationships between genotypes and body size in these two breeds. The model applied was: $Y_{i j k}=\mu+B_{i}+G_{j}+(B G)_{i j}+$ $e_{i j k}$, where $Y_{i j k}$ was the trait measured in each $i j k$ th animal, $\mu$ the overall population mean, $B_{i}$ the fixed effect due to the $i$ th breed, $G_{j}$ the fixed effect associated with $j$ th genotype, $(B G)_{i j}$ the interaction between the $i$ th breed and the $j$ th genotype, and finally $e_{i j k}$ the random error. Effects associated with farm, sex and season of birth (spring versus fall), as well as the ages of both dams and sires, were not used in the linear model, as the preliminary statistical analyses indi-

Table 1 - PCR primer sequence information and annealing temperatures.

\begin{tabular}{|c|c|c|c|}
\hline Gene loci & Primer sequences & Annealing temperatures $\left(\mathrm{X}^{\circ} \mathrm{C}\right)$ & Locations $^{\mathrm{a}}$ \\
\hline P1 & $\begin{array}{l}\text { F: 5'- ATTACAAAGCTGCCTGCCCC -3' } \\
\text { R:5'-ACCTTACCCGTATGAAAGGAATATACGT-3' }\end{array}$ & 60.3 & $1407-1655(249 \mathrm{bp})$ \\
\hline $\mathrm{P} 2$ & $\begin{array}{l}\text { F: 5'- TTCTCTAAATCCCTCTTCTGTTTG -3' } \\
\text { R: 5'- CCAATGACTTCAAAGAGTAAG -3' }\end{array}$ & 54.7 & $1942-2231(290 \mathrm{bp})$ \\
\hline P3 & $\begin{array}{l}\text { F: 5'- ACCCAGGAGGAAGATGACC -3' } \\
\text { R: 5'- ATCCACAGAGCAGCGAGA -3' }\end{array}$ & 65.7 & $4728-4956(229 \mathrm{bp})$ \\
\hline P4 & $\begin{array}{l}\text { F: 5'- GCTGGGTGTAGCAGTGAACA -3' } \\
\text { R: 5'- GTTGCTTCAGAAGCATAACT -3' }\end{array}$ & 60 & $5471-5790(320 \mathrm{bp})$ \\
\hline P5 & $\begin{array}{l}\text { F: 5'- GATAGGTTGGATACATAAA -3' } \\
\text { R: 5'- GTTGCGTAGAAAGAAGTG -3' }\end{array}$ & 55.8 & $6030-6580(550 \mathrm{bp})$ \\
\hline
\end{tabular}

${ }^{\mathrm{a} B a s e d}$ on GenBank accession: D26119.2. 
cated that these effects did not have significant influences on variability of traits in this two breeds. All the goats were adults, so the age did not influence on the body size. The least square means (LSMs), with standard errors and multiple range tests for $I G F-I$ genotypes and traits, were calculated.

Using PCR-SSCP method with five pairs of primers of the goat $I G F-I$ gene, only two (P1 and P4) of them demonstrated polymorphic patterns in both breeds. In the P1 locus (fragment amplified by the P1 pair of primers), there were only two kinds of SSCP polymorphic patterns detected in all the 708 samples. We named them GG, with three bands, and AG, with five bands (Figure 1a). In the P4 locus (fragment amplified by the $\mathrm{P} 4$ pair of primers), three SSCP polymorphic patterns were found in the 708 samples, which were named GG pattern, with four bands, CG pattern, with five bands, and $\mathrm{CC}$ pattern also with four bands (Figure 1b).

In order to clarify the nucleotide mutations in these two loci, nine PCR products, each with a different pattern, were sequenced at each locus. The three remaining products (P2, P3, and P5) were also sequenced. On comparing with GenBank sequence D26119.2, 249 bp PCR products, including the 5'-flanking region upstream from the start codon (ATG), were amplified by the PI pair of primers. There was a $\mathrm{G}$ to A mutation, namely g. $1617 \mathrm{G}>\mathrm{A}$ (accession D26119.2). The P4 primers were used to amplify the whole of exon 4 and part of introns 3 and 4 . There was a $\mathrm{G}$ to $\mathrm{C}$ variation in both breeds, viz., g. $5752 \mathrm{G}>\mathrm{C}$ (accession D26119.2), located in intron 4. No mutation was detected in the remaining loci (P2, P3, and P5).

The allelic and genotypic frequencies of each locus obtained for the different genetic groups, can be seen in Table 2. For the g. $1617 \mathrm{G}>$ A mutation (accession D26119.2), frequencies of the $I G F-I-A$ allele in the analyzed populations were 0.08 and 0.11 for GZ and SN dairy goats, respectively, with genotype distribution of both breeds in agreement with Hardy-Weinberg equilibrium ( $p>0.05)$. For the g.5752 G > C mutation (accession D26119.2), the GZ breed was not in Hardy-Weinberg equilibrium $(\mathrm{p}<0.01)$, whereas the SN breed was in Hardy-Weinberg equilibrium $(\mathrm{p}>0.05)$. The allelic frequencies for $\mathrm{C}$ were (a)

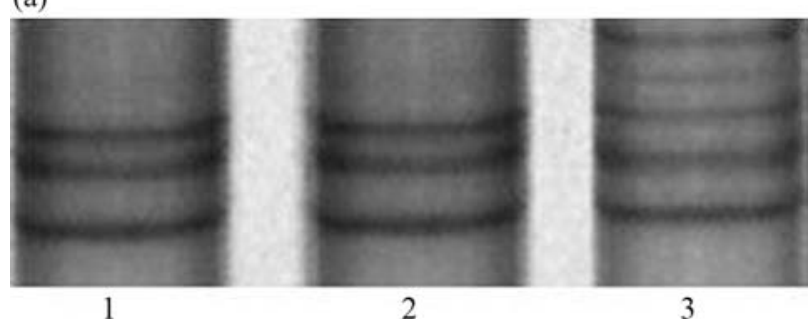

(b)

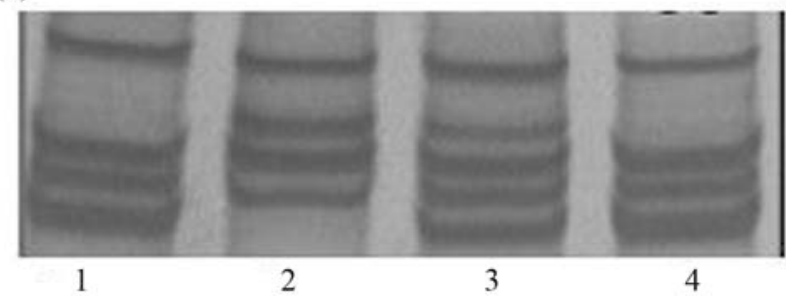

Figure 1 - (a) Different PCR-SSCP patterns in the 10\% PAGW in P1 locus. Lane 3 was AG pattern; lane 1, 2 were GG pattern. (b) Different PCR-SSCP patterns in the $10 \%$ PAGE in P4 locus. Lane 1, 4 were GG pattern; lane 2 was CC pattern; lane 3 was CG pattern.

0.19 and 0.30 for GZ and SN dairy goats, respectively (Table 2).

Combined data related to body-size and milk-yield at the first and second lactations are shown in Table 3. For g.1617 G > A (accession D26119.2), there was no significant association with body size and the milk yield in the two breeds ( $p>0.05)$. For g.5752 G > C (accession D26119.2), significant statistical results were encountered in milk yield and BL (body length) of individuals with the $\mathrm{CC}$ and $\mathrm{CG}$ genotypes ( $p<0.05$ and $p<0.05$, respectively) in Saanen dairy goats. The BL of SN breed with CG genotype was significantly longer than in the others. Individuals with genotype CC of the $I G F-I$ gene had a superior milk yield at the first and second location when compared to those of individuals with genotype $\mathrm{CG}$ and $\mathrm{GG}(\mathrm{p}<0.05)$. In the Guanzhong population, chest circumference $(\mathrm{ChC})$ of $\mathrm{GZ}$ goats with the GG genotype was the largest of the three genotypes, whereas $\mathrm{ChC}$ for individuals with $\mathrm{CG}$ genotype was larger than that for $\mathrm{CC}$ carriers $(\mathrm{p}<0.05)$.

When focusing on the IGF-I gene, an attempt was made to detect nucleotide mutations in primer amplified

Table 2 - Allelic and genotypic frequencies of P4 and P1 in Chinese dairy goats.

\begin{tabular}{|c|c|c|c|c|c|c|c|c|c|c|c|}
\hline \multirow[t]{2}{*}{ Gene loci } & \multirow[t]{2}{*}{ Breeds } & \multicolumn{4}{|c|}{ Genotypes } & \multicolumn{3}{|c|}{ Genotypic frequencies } & \multicolumn{2}{|c|}{ Allelic frequencies } & \multirow{2}{*}{$\begin{array}{l}\text { Hardy-Weinberg equilibrium } \\
\qquad\left(\chi^{2} \text { test }\right)\end{array}$} \\
\hline & & GG & AG & AA & $\mathrm{N}$ & $\mathrm{P}_{\mathrm{GG}}$ & $\mathrm{P}_{\mathrm{AG}}$ & $\mathrm{P}_{\mathrm{AA}}$ & $\mathrm{P}_{\mathrm{A}}$ & $\mathrm{P}_{\mathrm{G}}$ & \\
\hline \multirow[t]{3}{*}{$\mathrm{P} 1$} & GZ & 373 & 67 & 0 & 440 & 0.85 & 0.15 & 0 & 0.08 & 0.92 & 2.98 \\
\hline & $\mathrm{SN}$ & 211 & 57 & 0 & 268 & 0.79 & 0.21 & 0 & 0.11 & 0.89 & 3.79 \\
\hline & & $\mathrm{CC}$ & $\mathrm{CG}$ & GG & $\mathrm{N}$ & $\mathrm{P}_{\mathrm{CC}}$ & $\mathrm{P}_{\mathrm{CG}}$ & $\mathrm{P}_{\mathrm{GG}}$ & $\mathrm{P}_{\mathrm{C}}$ & $\mathrm{P}_{\mathrm{G}}$ & \\
\hline \multirow[t]{2}{*}{ P4 } & $\mathrm{GZ}$ & 47 & 69 & 324 & 440 & 0.10 & 0.16 & 0.74 & 0.19 & 0.81 & $101.56(\mathrm{p}<0.01)$ \\
\hline & $\mathrm{SN}$ & 22 & 116 & 130 & 268 & 0.08 & 0.43 & 0.49 & 0.30 & 0.70 & 0.30 \\
\hline
\end{tabular}

$\chi_{0.05}^{2}(\mathrm{df}=1)=3.84, \chi_{0.01}^{2}(\mathrm{df}=1)=6.63$. 
Table 3 - Relationship between genotypes and body size and milk yield in Chinese dairy goats.

\begin{tabular}{|c|c|c|c|c|c|c|c|}
\hline \multirow[t]{2}{*}{ Gene loci } & \multirow[t]{2}{*}{ Breeds } & \multirow[t]{2}{*}{ Genotypes } & \multicolumn{3}{|c|}{ Body size (mean $\pm \mathrm{SE})$} & \multicolumn{2}{|c|}{ Milk yield (mean $\pm \mathrm{SE})$} \\
\hline & & & $\mathrm{BH}(\mathrm{cm})$ & $\mathrm{BL}(\mathrm{cm})$ & $\mathrm{ChC}(\mathrm{cm})$ & First lactation $(\mathrm{kg})$ & Second lactation $(\mathrm{kg})$ \\
\hline & $\mathrm{GZ}$ & GG & $67.92 \pm 0.20$ & $77.62 \pm 0.26$ & $92.38 \pm 2.39$ & No record & No record \\
\hline & & $\mathrm{AG}$ & $67.50 \pm 0.47$ & $76.77 \pm 0.63$ & $89.82 \pm 5.67$ & No record & No record \\
\hline \multirow[t]{5}{*}{$\mathrm{P} 1$} & SN & GG & $74.34 \pm 0.24$ & $82.90 \pm 0.28$ & $92.56 \pm 0.37$ & $627.218 \pm 7.661$ & $855.868 \pm 10.404$ \\
\hline & & $\mathrm{AG}$ & $74.91 \pm 0.46$ & $82.67 \pm 0.54$ & $93.22 \pm 0.71$ & $621.858 \pm 15.017$ & $841.138 \pm 19.798$ \\
\hline & GZ & $\mathrm{CC}$ & $67.04 \pm 0.57$ & $76.94 \pm 0.77$ & $87.45 \pm 0.89^{\mathrm{b}}$ & No record & No record \\
\hline & & CG & $67.10 \pm 0.47$ & $76.74 \pm 0.63$ & $89.29 \pm 0.73^{\mathrm{ab}}$ & No record & No record \\
\hline & & GG & $67.89 \pm 0.21$ & $77.65 \pm 0.29$ & $90.22 \pm 0.33^{\mathrm{a}}$ & No record & No record \\
\hline \multirow[t]{3}{*}{ P4 } & SN & $\mathrm{CC}$ & $74.57 \pm 0.78$ & $81.47 \pm 0.89^{b}$ & $91.10 \pm 1.14$ & $679.307 \pm 23.718^{a}$ & $940.317 \pm 42.748^{\mathrm{a}}$ \\
\hline & & CG & $74.57 \pm 0.32$ & $83.46 \pm 0.37^{\mathrm{a}}$ & $93.04 \pm 0.48$ & $622.313 \pm 7.965^{\mathrm{b}}$ & $858.094 \pm 11.856^{\mathrm{ab}}$ \\
\hline & & GG & $74.05 \pm 0.31$ & $81.95 \pm 0.35^{\mathrm{b}}$ & $92.25 \pm 0.45$ & $616.236 \pm 7.525^{\mathrm{b}}$ & $833.978 \pm 14.808^{b}$ \\
\hline
\end{tabular}

LSM in a column with no common superscripts differs significantly; low-case character represents significance at $\mathrm{p}<0.05$.

fragments, and to analyze their associations with body size and milk yield in Chinese dairy goats. The analyzed length of the $I G F-I$ gene was $1588 \mathrm{bp}$, including part of the 5'flanking, and almost the entire coding region except for exon 2 which is only $15 \mathrm{bp}$ long. In the g. $1617 \mathrm{G}>\mathrm{A}$ mutation (accession D26119.2), the lack of AA homozygotes indicated that the mutation in the goat $I G F-I$ gene might give rise to diminished production in the population under analysis. These two dairy goat breeds are major milk producers, originating from a varied dairy-goat breeding basis in Shaanxi province (P.R. China). As the two populations were over one year old, individuals with low production had possibly already been eliminated. Hence, it is reasonable to surmise that AA homozygotes is almost completely lost in quite large local populations. Obviously, the reason of the lack of genotype AA in these breeding farms requires further investigation.

Significant statistical results were found as regards body size and milk yield among different genotypes in g.5752 G > C (accession D26119.2) (p < 0.05) (Table 3). Being located in one of the intron regions, the SNP studied here may not be a causal mutation. Thus, we suggest that it could be linked to another mutation in the coding or regulatory regions of a gene which is a causal mutation for production traits. Introns have been shown to affect the transcriptional efficiency of numerous genes in a variety of organisms (Greenwood and Kelsoe, 2003; LeHir et al., 2003). Further analysis is required to validate both the association found in this study and the physiological significance of the intron 4 mutation in $I G F-I$ gene.

In conclusion, our study revealed the first known significant associations of $I G F-I$ gene polymorphisms with milk yield and body size in dairy goats. The CC genotype at the g.5752 G > C (accession D261 19.2) locus could be used as a molecular marker for superior milk yield. Furthermore, this study will be of practical use for the improvement of
Chinese native dairy goats and the local breeding of those with higher milk production.

\section{Acknowledgments}

This study was supported by the National 863 Program of China (No. 2008AA10Z138), the Young Topnotch Researcher Support Project of Northwest A\&F University (No.QNGG-2009-007), the "13115" Sci-Tech Innovation Program of Shaanxi Province (No. 2008ZDKG-11), the Research Fund for the Doctor Program of Higher Education of China (No.20080712001), and the Natural Science Foundation of Jiangsu Province (No. BK2008120).

\section{References}

Adam CL, Gadd TS, Findlay PA and Wathes DC (2000) IGF-I stimulation of luteinizing hormone secretion, IGF-binding proteins (IGFBPs) and expression of mRNAs for $I G F S, I G F$ receptors and $I G F B P$ s in the bovine pituitary gland. J Endocrinol 166:247-254.

Barash H, Aharoni Y, Brosh A and Holzer Z (1998) Effect of low energy diets followed by a compensatory diet on body weight gain and plasma hormone concentrations in bull calves. J Dairy Sci 81:250-254.

Curi RA, Oliveira HN, Silveira AC and Lopes CR (2005) Effects of polymorphic microsatellites in the regulatory region of $I G F-I$ and $G H R$ on growth and carcass traits in beef cattle. Livest Prod Sci 94:159-167.

Daughaday WH and Rotwein P (1989) Insulin-like growth factors I and II. Peptide messenger ribonucleic acid and gene structures, serum and tissue concentrations. Endocr Rev 10:6891.

Eulalia S, Lech, Z, Jolanta O, Nina S, Emilia B and Krzyzewski J (2006) Effect of polymorphism in $I G F-I$ gene on production traits in Polish Holstein-Friesian cattle. Anim Sci Pap Rep 24:225-237.

Ge W, Davis ME, Hines HC, Irvin KM and Simmen RC (2001) Association of a genetic marker with blood serum insu- 
lin-like growth factor-I concentration and growth traits in Angus cattle. J Anim Sci 79:1757-1762.

Greenwood TA and Kelsoe JR (2003) Promoter and intronic variants affect the transcriptional regulation of the human dopamine transporter gene. Genome 82:511-520.

Hines HC, Ge W, Zhao Q and Davis ME (1998) Association of genetic markers in growth hormone and insulin-like growth factor I loci with lactation traits in Holsteins. Anim Genet 29:69.

Kim ES, Shi X, Cobanoglu O, Weigel K, Berger PJ and Kirkpatrick BW (2009) Refined mapping of twinning rate quantitative trait loci on bovine chromosome 5 and analysis of insulin-like growth factor-I as a positional candidate gene. J Anim Sci 87:835-843.

Lan XY, Pan CY, Chen H, Zhang CL, Li JY and Zhao M (2007) An AluI PCR-RFLP detecting a silent allele at the goat POUIFI locus and its association with production traits. Small Ruminant Res 73:8-12.

LeHir H, Nott A and Moore M (2003) How introns influence and enhance eukaryotic gene expression. Trends Biochem Sci 28:215-220.

Li C, Basarab J, Snelling WM, Benkel B, Murdoch B, Hansen C and Moore SS (2004) Assessment of positional candidate genes $m y f 5$ and $I G F-I$ for growth on bovine chromosome 5 in commercial lines of Bos taurus. Anim Sci 82:1-7.

Miller JR, Thomsen PD, Dixon SC, Tucker EM, Konfortov BA and Harbitz I (1991) Synteny mapping of the bovine IGHG2, CRC and IGF-I genes. Anim Genet 23:51-58.
Moody DE, Pomp D, Newman S and Macheil MD (1996) Characterization of DNA polymorphisms in three populations of Hereford cattle and their associations with growth and maternal EPD in line 1 Herefords. J Anim Sci 74:1784-1793.

Nixon AJ, Brower-Toland BD and Sanell LJ (1999) Primary nucleotide structure of predominant and alternate splice forms of equine insulin-like growth factor I and their gene expression patterns in tissues. Am J Vet Res 60:1234-1241.

Sambrock J, Fritsch EF and Maniatis T (2001) Molecular Cloning: A Laboratory Manual. 3rd edition. Cold Spring Harbor, New York.

Sellier P (2000) Genetically caused retarded growth in animals. Domest Anim Endocrinol 19:105-119.

Shen WH, Wisniowski P, Ahmed L, Boyle DW, Denne SC and Liechty EA (2003) Protein anabolic effects of insulin and $I G F-I$ in the ovine fetus. Am J Physiol Endocrinol Metab 284:E748-E756.

Sirotkin AV, Chrenek P, Makarevich AV, Huba J and Bulla J (2000) Interrelationships between breed, growth hormone, plasma IGF-I level and meat performance in bulls of different ages. ArchTierzucht 6:591-596.

Wang Y, Price SE and Jiang H (2003) Cloning and characterization of the bovine class 1 and class 2 insulin-like growth factor-I mRNAs. Domest Anim Endocrinol 25:315-328.

Associate Editor: Bertram Brenig

License information: This is an open-access article distributed under the terms of the Creative Commons Attribution License, which permits unrestricted use, distribution, and reproduction in any medium, provided the original work is properly cited. 